\title{
Prolactin Secretion and Its Response to Stress During the Estrous Cycle of the Rats
}

\author{
Sen-ichi FURUDATE, Hisayo ASHIHARA, and Takeshi NAKANO \\ Department of Laboratory Animal Science, School of Medicine, \\ Kitasato University, 1-15-1 Kitasato, \\ Sagamihara-shi, Kanagawa 228, Japan
}

(Received 17 March 1989/Accepted 2 June 1989)

\begin{abstract}
Serum and pituitary prolactin (PRL) concentrations were measured during the estrous cycle of the rat with particular attention to the afternoons of the days of proestrus and estrus. Homogenizing machines, a Polytron and Sonifier, were used to extract PRL from the pituitary gland. The effects of ether anesthesia and restraint were also examined on the afternoons of both proestrus and estrus. The occurrence of a surge in PRL secretion during proestrus was confirmed with a peak at $1500 \mathrm{~h}$, and this was accompanied by a decline in pituitary PRL content. A relatively high level of serum PRL was observed in the afternoon of estrus, during which time pituitary PRL content increased progressively. Ether anesthesia had no effect on the proestrous PRL surge, while restraint enhanced it. On the afternoon of estrus, restraint completely suppressed the rise in serum PRL, but ether anesthesia failed to suppress it completely. From these results, the following conclusions were drawn : 1) the PRL surge on the afternoon of proestrus occurs without synthesis of the hormone in the pituitary; 2) PRL secretion on the afternoon of estrus is accompanied by its synthesis in the gland ; 3 ) the PRL response is distinct for each type of stress applied ; and 4) PRL secretion is thus regulated by different mechanisms in proestrus and estrus.
\end{abstract}

Many reports are available describing changes in pituitary and serum prolactin(PRL) levels during the estrous cycle of the rat. A surge in PRL secretion in the afternoon and evening of proestrus has been observed and confirmed repeatedly by many investigators $[2,14,15,18,23]$. In some cases, high levels of serum PRL have been found in the afternoon of estrus $[1,3,4]$. During the estrous cycle pituitary PRL content has been found to be high during proestrus and estrus $[1,10,11,21]$, however, differing values have been reported for pituitary PRL content.

The present study was conducted to determine pituitary and serum PRL levels during the estrous cycle, in particular, in the afternoons of proestrus and estrus, in the same samples. Homogenizing machines, a Polytron and Sonifier, were used to extract PRL from the pituitary gland. Because PRL levels in the circulation are affected by stress $[3,6,17,19$,
$20,22]$ special attention was also directed to the influence of ether anesthesia and restraint on PRL secretion during both proestrus and estrus.

\section{Materials and Methods}

Female Wistar-Imamichi strain rats were purchased from the Imamichi Institute for Animal Reproduction (Omiya, Japan) at 9 weeks of age. They were kept under controlled illumination (lights on from $0500 \mathrm{~h}$ to $1900 \mathrm{~h}$ ) at $24 \pm 1^{\circ} \mathrm{C}$ and a relative humidity of 50 60\%. Rat chow (Oriental Kobo Co., Ltd., Tokyo) was the food source and water was available at all times. Vaginal smears were examined, and only rats exhibiting regular 4-day estrous cycles were used.

In the first experiment, 5 animals were placed in each group according to the stage of estrous. To obtain blood samples, the rats 
were killed by decapitation within a minute after being taken from their cages at the following times : $1200 \mathrm{~h}$ on the first and second days of diestrus, $1200 \mathrm{~h}, 1500 \mathrm{~h}, 1800 \mathrm{~h}$ and $2100 \mathrm{~h}$ on the day of proestrus, and $1200 \mathrm{~h}, 1500 \mathrm{~h}$ and $1800 \mathrm{~h}$ on the day of estrus. Blood was taken from their trunks and placed into centrifuge tubes which were subsequently placed in an ice bath, and clotting was allowed to occur. The sera were separated by centrifugation at $4^{\circ} \mathrm{C}$.

Immediately after the rats had been sacrificed the anterior pituitary was removed and divided into two parts (each termed a hemi -pituitary), with the wet weights of each part being determined separately. One hemi-pituitary was homogenized with a Polytron (homogenizer; Kinematica) for 30 seconds in $2.0 \mathrm{ml}$ of $0.01 \mathrm{M}$ phosphate buffer containing $0.14 \mathrm{M}$ saline $(\mathrm{pH} 7.6)$, while all the others were disrupted with a Sonifier (Branson) in $1.5 \mathrm{ml}$ of the buffer for 20 seconds. Both types of pituitary samples were centrifuged at $3000 \mathrm{rpm}$. for 20 minutes at $4{ }^{\circ} \mathrm{C}$, and the supernatants were decanted into sample tubes. Individual serum and supernatant samples were maintained below $-20^{\circ} \mathrm{C}$ until hormone assay.

In the second experiment, blood samples were obtained at $1500 \mathrm{~h}$ on the day of estrus and $1700 \mathrm{~h}$ on the day of proestrus in the following 3 ways : 1) from the trunks of the control animals following decapitation, as in the first experiment ; 2) from the trunks of the ether anesthesia group, after having first been anesthetized by placing the animals in a jar completely saturated with ether for 2 minutes ; and 3) from the jugular vein of the restraint group, the animals having been placed in the supine position on a restraining table, their heads fixed by retracting the incisors in the cranial direction and their forelimbs clipped together, for 2 minutes.

Pituitary and serum PRL concentrations were measured by radioimmunoassay (RIA), each in duplicate, using reagents from NIADDK and radioiodinated rat PRL purchased from New England Nuclear, MA, USA. rPRL-RP-3 was used as the reference standard. Intra-and inter-assay coefficients of variation in this assay were 9.6 and $15.9 \%$, respectively.

Significant differences were calculated using Student's t-test, with a value of $p<0.05$ considered significant.

\section{Results}

Changes in Serum PRL : Changes in serum PRL levels during the estrous cycle are summarized in Fig. 1. They were low (basal level) at $1200 \mathrm{~h}$ on the first and second days of diestrus. On the day of proestrus, the level of serum PRL at $1500 \mathrm{~h}$ was significantly higher than at 1200 $\mathrm{h}(\mathrm{p}<0.01)$. From $1500 \mathrm{~h}$ to $2100 \mathrm{~h}$, it decreased sharply $(p<0.01)$. The levels were high at $1200 \mathrm{~h}$ and $1500 \mathrm{~h}$ on the day of estrus, but decreased sharply by $1800 \mathrm{~h}$ on the same day $(p<0.01)$.

Changes in Pituitary PRL : Changes observed during the estrous cycle are summarized in Fig. 2. Pituitary PRL concentrations determined using the Sonifier were higher than after

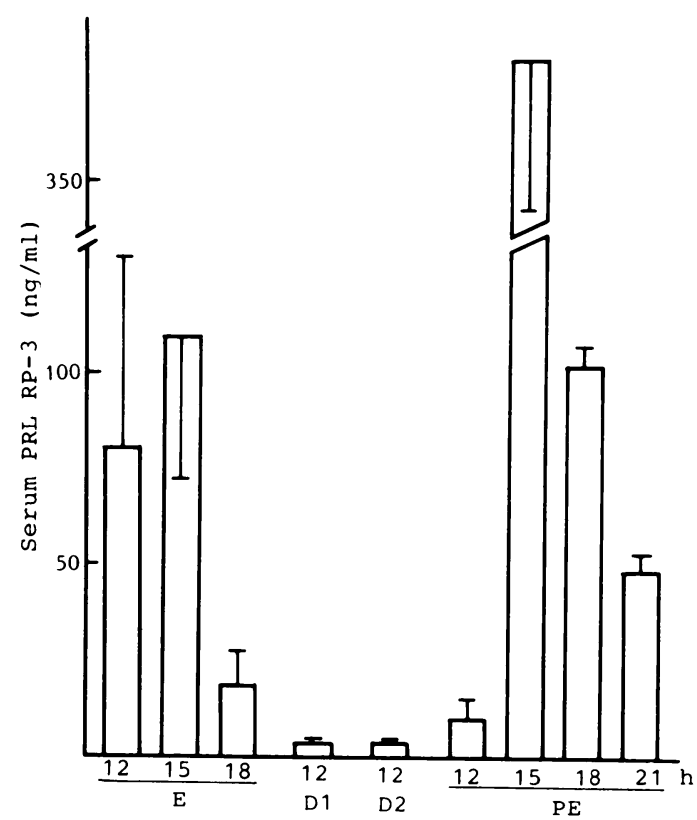

Fig. 1. Serum PRL levels during the estrous cycle of the rat. The animals were killed by decapitation. The vertical lines indicate S. E. M. The values at $1200 \mathrm{~h}$ and $1500 \mathrm{~h}$ obtained during estrus differed significantly from those at $1800 \mathrm{~h}$ on the same day $(\mathrm{p}<0.01)$. The values obtained during proestrus differed significantly from each other $(p<0.01)$. Estrus, first diestrus, second diestrus, and proestrus are abbreviated E, D 1, D 2 and PE, respectively. 


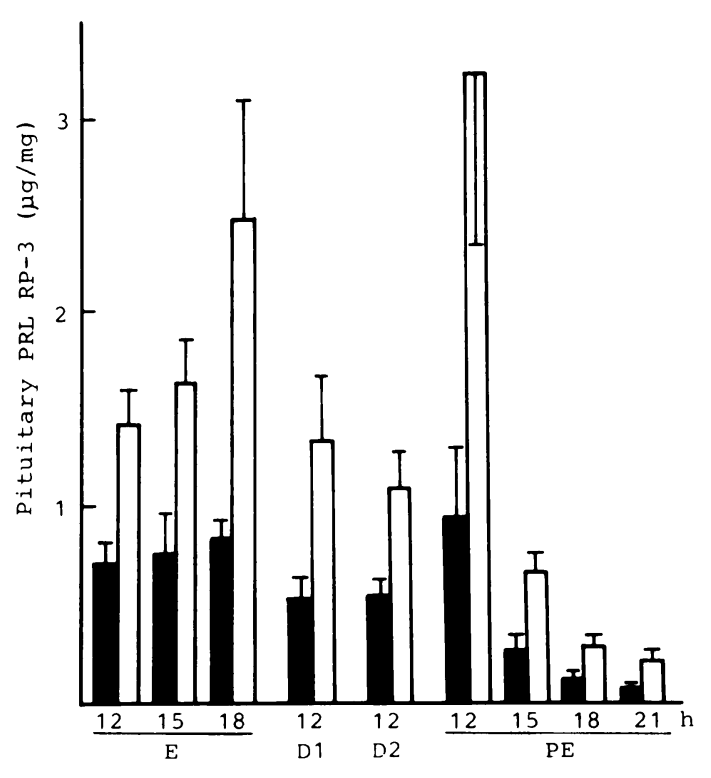

Fig. 2. Pituitary PRL concentrations during the estrous cycle of the rat. PRL values obtained using the Polytron are shown in the black columns. PRL valves using the Sonifier are shown in the white columns. They are expressed as means and S. E. M. PRL at 1800 $\mathrm{h}$ during estrus as determined using the Sonifier significantly exceeded at $1200 \mathrm{~h}$ or $1500 \mathrm{~h}$ on the same day $(p<0.01)$. PRL at 1200 $\mathrm{h}$ levels during proestrus as measured using both the Polytron and Sonifier differed significantly from levels at $1500 \mathrm{~h}, 1800 \mathrm{~h}$ and $2100 \mathrm{~h}$ on the same day $(\mathrm{p}<0.01)$.

homogenization by the Polytron at each of the times they were measured during the estrous cycle. A similar difference was found in pituitary PRL concentrations in the Polytron and Sonifier groups. Moreover, the changes in PRL concentration determined using the Sonifier were considerably higher $(2.0-3.4$ times) than after Polytron extraction. The values obtained with the Sonifier were thus used for purposes of comparison.

Pituitary PRL hardly fluctuated at all during the first and second days of diestrus and remained midrange. However, it did change markedly during proestrus and estrus. On the day of proestrus, pituitary PRL content was highest at $1200 \mathrm{~h}$ but dropped sharply from $1200 \mathrm{~h}$ to $1500 \mathrm{~h}(\mathrm{p}<0.01)$, and continued to decline from $1500 \mathrm{~h}$ to $2100 \mathrm{~h}(\mathrm{p}<0.01)$. During
Table. 1. Effects of restraint and ether anesthesia on serum PRL levels at $1700 \mathrm{~h}$ on the day of proestrus. Blood samples were obtained from the trunks of the control animals following decapitation. The same procedure was followed for the ether group after first anesthetizing the animals. Blood samples were taken from the restraint group via the jugular vein with the animals in supine position on a restraining table. PRL values for the immobilization group increased significantly beyond those of the controls ${ }^{*} \mathrm{p}<0.05$.

\begin{tabular}{lc}
\hline Group & Serum PRL ng/ml (Mean \pm S.E.M.) \\
\hline Control & $139.3 \pm 8.21$ \\
Restraint & $204.3 \pm 17.42^{*}$ \\
Ether & $121.0 \pm 10.82$ \\
\hline
\end{tabular}

Table.2. Effects of restraint and ether anesthesia on serum prolactin levels at $1500 \mathrm{~h}$ on the dayof estrus. Methods for blood collecting were the same as in Table 1. The PRL values in both the restraint and ether anesthesia groups differed significantly from those of the decapitation control group and were $^{* *} p<0.01$ and ${ }^{*} p<0.05$, respectively.

\begin{tabular}{lc}
\hline Group & Serum PRL ng/ml (Mean \pm S.E.M.) \\
\hline Control & $127.2 \pm 21.33$ \\
Restraint & $6.0 \pm 2.22^{* *}$ \\
Ether & $50.8 \pm 21.80^{*}$ \\
\hline
\end{tabular}

the day of estrus, however, there was a gradual increase from $1200 \mathrm{~h}$ to $1800 \mathrm{~h}(\mathrm{p}<0.01)$.

Serum PRL Levels Following Stress Stimuli : Tables 1 and 2 show serum PRL levels following application of stress stimuli. On the afternoon of proestrus (Table 1), although serum PRL in the ether anesthesia group was lower than in the control group, there was no statistically significant difference between the two groups. In the restraint group, serum PRL was significantly elevated beyond the levels of the control group $(p<0.05)$.

On the afternoon of estrus (Table 2 ), on the other hand, 2 of 5 animals in the ether anesthesia group had levels equal to those of the control group, while the levels of the others were lower $(p<0.05)$. Suppressed levels of serum PRL were observed in all of the rats 
in the restraint group $(p<0.01)$.

\section{Discussion}

Measurement of serum PRL in the first experiment confirmed that, although serum PRL concentrations are at basal level on the first and second days of diestrus, a surge in PRL secretion occurs on the afternoon of proestrus with a peak level at $1500 \mathrm{~h}$ and relatively high levels on the afternoon of estrus. This surge on the afternoon of proestrus has been confirmed in many other studies as mentioned above. High PRL levels in serum or plasma on the day of estrus, however, have been reported in only a few cases $[1,3,5]$. This contradiction in previous reports may be due to the fact that, in addition to the rat strains employed and the time of blood collection, circulating PRL levels are sensitive to stress and affected by the various methods used to obtain blood samples, which will be mentioned later.

Some of the PRL present in the pituitary is expected not to be extracted by the usual method, which uses a homogenizer, and in addition, secretory granules containing PRL particles may not be disrupted by the isotonic buffer $[9,24]$. PRL particles have a strong affinity toward the component comprising the cell membranes $[12,13,19,24]$. In the present study, in order to carry out PRL extraction successfully, a Polytron and Sonifier were used for homogenization and cell disruption. The values obtained using the Polytron were less than those obtained with the Sonifier. It is thus evident that the pituitary contains PRL which is not extractable by the usual method employing only a homogenizer. However, the possibility remains that the values obtained using the Sonifier do not reflect all of the PRL in the pituitary, since even after ultrasonic treatment the pellets still exhibit numerous PRL granules, although these are devoid of enveloping membranes [9].

The decrease in pituitary PRL content observed on the afternoon of proestrus coincides with the surge observed in serum PRL, indicating that PRL is secreted by the pituitary without being synthesized in the gland. This decrease has also been reported by Taya and Igarashi [23] and Blank et al. [2], employing the usual homogenizer to extract
PRL from the pituitary. The degree of decline in values reported in this study was more extreme when the Sonifier was used than when the Polytron was used as can be seen in Fig. 2. An abrupt drop in pituitary PRL concentration has been detected recently in pituitary homogenates treated with Triton $\mathrm{X}^{-}$ 100 during the afternoon of proestrus [13].

In addition, high concentrations of pituitary PRL were noted on the afternoon of estrus, and serum PRL levels were also observed to be high during this period. There are no previous repors dealing with pituitary PRL during the afternoon of estrus. High PRL content in the pituitary during the morning of estrus has been claimed in a few reports $[10,11]$. Ieiri et al. [11] also reported that the synthesis and release of PRL were significantly higher in the morning of estrus than at any other stage of the estrous cycle. Many researchers have failed to detect high pituitary PRL on the day of estrus. It is likely that insufficient care was exercised during this period and/or that they used the usual method for PRL extraction from the pituitary. Our data, which show high pituitary PRL concentrations on the afternoon of estrus, indicate that the release and synthesis of PRL by the pituitary occur simultaneously during this period.

The data obtained in the second experiment reveal that stress affects serum PRL levels differently during the proestrus and estrus days of the estrous cycle, with the response depending on the type of stress applied. On the afternoon of proestrus (Table 1), ether anessthesia failied to have any significant effect on serum PRL levels, whereas restraint caused an increase. On the afternoon of estrus (Table 2 ). on the other hand, both ether anesthesia and restraint had affected serum PRL levels. PRL in the forced restraint groups was suppressed in all of the rats, but in the ether anesthesia group, suppreession was detected inonly 3 of the 5 rats.

In general, stress results in an increase in serum and plasma PRL when PRL levels are basal $[16,17,19]$. Conversely, stress evokes a decrease in PRL when it is applied during the proestrous PRL surge, including the estrogeninduced PRL surge in ovariectomized rats $[7,8,16,17]$. It is thus evident that the response of PRL secretion to stress differs 
depending on the animal's physiological state [19]. Our findings presented here conflict with previous reports concerning the afternoon of proestrus. This discrepancy might be explained on the basis of the sampling interval after the initiation of stress and the intensity of the stress. Changes in PRL levels varied with time after exposure to ether stress, i. e., an increase in PRL occurred in the initial period following ether stress and a decrease in PRL occurred toward the end [25]. We assume that the time and type of stress employed are important factors affecting PRL values measured by blood collection. In the present study only a short time ( 2 minutes from stress exposure till blood collection) elapsed after stress. At the very least it can be said that serum PRL levels during or after stress vary markedly with the physiological state of the estrous cycle.

Based on the results presented in this study, we conclude that PRL secretion in the afternoons of proestrus and estrus is regulated by different mechanisms in each of these stages.

We are grateful to Dr. A. F. Parlow and the Rat Pituitary Hormone Distribution Program, NIADDK, NIH, U. S. A. for providing the PRL RIA kit. We also wish to thank Mr. H. Zompa for his valuable discussion on this manuscript.

\section{References}

[1] Amenomori, Y., Chen, C. L., and Meites, J. (1970). Serum prolactin levels in rats during different reproductive states. Endocrinology, 86, 506-510.

[2] Blank, M. S., Melvin, C. C., and Dufau, M. L.(1986). Bioactivity of serum and pituitary prolactin during the rat estrous cycle. Endocrinology, 118, 18861891.

[3] Boehm, N., Plas-Roser, S., Lazarus, C., and Aron, C. (1982). Influence of blood removal under ether anesthesia on the release of prolactin during the oestrous cycle in the rat. Involvement of the ovaries. Acta Endocrinol, 99, 179-186.

[4] Boehm, N., Plas-Roser, S., and Aron, C. (1984). Prolactin and the control of cycle length in the female rat. Acta Endocrinol, 106, 188-192.

[5] Butcher, R. L., Collins, W. E., and Fugo, N. W. (1974). Plasma concentration of LH, FSH, prolactin, progesterone and estradiol-17 $\beta$ throughout the 4day estrous cycle of the rat. Endocrinology, 94, 1704-1708.

[6] Caligaris, L. and Taleisnik, S. (1983). Prolactin release induced by stress and influence of oestrogen and progesterone treatments, sex and daily rhythm. Acta Endocrinol, 102, 505-510.

[7] Gala, R. R. and Haisenleder, D. J. (1982). Stressinduced decrease of the afternoon prolactin surge.
The influence of thr adrenal gland. Life Sci, 31 , 875-879.

[8] Gala, R. R. and Haisenleder, D. J. (1986). Restraint stress decreases afternoon plasma prolactin levels in female rats. Influence of neural antagonists and agonists on restraint-induced changes in plasma prolactin and corticosterone. Neuroendocrinology, 43, 115-123.

[9] Haggi, E and Aoki, A. (1981). Prolactin concentration in rat pituitary gland. RIA of prolactin after different extraction procedures. Acta Endocrinol, 97, 338-342.

[10] Ieiri, T., Akikusa, Y., and Yamamoto, K. (1971). Synthesis and release of prolactin and growth hormone in vitro during the estrous cycle of the rat. Endocrinology, 89, 1533-1537.

[11] Ieiri, T., Nobunaga, T., and Yamanoto, K. (1972). Fluctuations in the synthesis and release of prolactin by the anterior pituitary of the rat during the oestrous cycle. J. Endocrinol, 55, 451-452.

[12] Ishikawa, J, Fuse, Y., and Wakabayashi, K. (1987). Choice of extraction procedure for estimation of anterior pituitary hormone content. Endocrinol Japon, 34, 755-767.

[13] Kawaminami, M., Imase, S., Hara, C , and Hashimoto, I. (1986). Changes in pituitary prolactin (PRL) concentrations during the proestrous PRL surge in the rat. In Pars Distalis of the Pituitary Gland, pp. 435-438. Yoshimura, F. and Gorbman, A. (eds), Elsevier Science Publishers B. V.

[14] Klindt, J., Robertson, M., C., and Friesen, H. G. (1982). Episodic secretory patterns of rat prolactin determined by bioassay and radioimmunoassay. Endoc rinology, 111, 350-352.

[15] Leung, F. C., Russell, S. M., and Nicoll, C. S. (1978). Relationship between bioassay and radioimmunoassay estimates of prolactin in rat serum. Endocrinology, 103, 1619-1628.

[16] Morishige, W. K. and Rothchild, I. (1974). A paradoxical inhibiting effect of ether on prolactin release in the rat : comparison with effect of ether on LH and FSH. Neuroendocrinology, 16, 95-107.

[17] Neill, J. D. (1970). Effect of "stress" on serum prolactin and luteinizing hormone levels during the estrous cycle of the rat. Endocrinology, 87, 11921197.

[18] Neill, J. D., Freeman, M. E., and Tillson, S. A. (1971). Control of the proestrus surge of prolactin and luteinizing hormone secretion by estrogens in the rat. Endocrinology, 89, 1448-1453.

[19] Riegle G. D. and Meites, J. (1976). The effect of stress on serum prolactin in the female rat. Proc. Soc. Exp. Biol Med, 152, 441-448.

[20] Reier, P. J., Morishige, W. K., and Rothchild, I. (1974). The effect of ether and laparotomy on serum prolactin levels in progesterone-treated intact and ovariectomized rats. Neuroendocrinology, 16, 43-51.

[21] Sar, M. and Meites, J. (1967). Changes in pituitary prolactin release and hypothalamic PIF content during the estrous cycle of rats. Proc. Soc. Exp. Biol Med, 125, 1018-1021.

[22] Smith S. W. and Gala, R. R. (1977). Influence of restraint on plasma prolactin and corticosterone in 
female rats. $J$. Endocrinol, 74, 303-314.

[23] Taya, K. and Igarashi, M. (1973). Changes in FSH, $\mathrm{LH}$ and prolactin secretion during estrous cycle in rats. Endocrinol Japon, 20, 199-205.

[24] Torres, A. I., Haggi, E. S., and Aoki, A. (1984).
Isolation of two different pools of pituitary prolactin. Acta Endocrinol, 107, 25-30.

[25] Turpen, C., Johnson D. C., and Dunn, J. D. (1976). Stress induced gonadotropin and prolactin secretory patterns. Neuroendocrinology, 20, 339-351.

ラット発情周期に括けるプロラクチン分泌と ストレスに対する反応

古舘専一・芦原久代・中野健司

北里大学医学部実験動物学教室

ラット発情周期, 特に発情前期および発情期における 血清と下垂体中のプロラクチン (PRL) 濃度が測定され た。下垂体は二分割して，ポリトロン(ホモゲナイザー) 或はソニファイアー（超音波）で抽出処理された。発情 前期の午後 3 時に PRL サージが確認された。このPRL サージは下垂体 PRL 含量の減少を伴った。発情期の午 後にも比較的高いレベルの PRL 分泌がみられた。この PRL 分泌時には下垂体の PRL 含量は增加した。発情 前期と発情期の PRL 分泌に対するェーテル麻酔拉よび 拘束保定の影響が検討された。エーテル麻酔は発情前期
のPRLサージに影響を及ぼさなかったが，拘束保定は PRL 分泌を上昇させた。発情期の午後，PRL 分泌は 拘束保定によって完全に抑制されたが，ェーテル麻酔て は不完全な抑制がみられた。以上から，次の結論がえら れた。1）発情前期の PRL サージは下垂体での PRL 合成なしに起こる。2）発情期の PRL 分泌は下垂体で の PRL の合成を伴う。3）発情前期怙よび発情期の PRL 分泌は与えられたストレスに対して異なる反応を 示す。4）発情前期および発情期の PRL 分泌は異なる 支配機構下に在ることが示唆された。 